\title{
An Investigation into the Effectiveness of Asynchronous and Synchronous E-learning Mode on Students' Academic Performance in National Open University (NOUN), Maiduguri Centre
}

\author{
Emmanuel G. Dada and Abdulkadir H. Alkali \\ Department of Computer Engineering, Faculty of Engineering, University of Maiduguri, Borno state, Nigeria \\ Email: \{gbengadada, ahalkali\}@unimaid.edu.ng \\ David O. Oyewola \\ Department of Mathematics and Computer Science, Federal University Kashere, Gombe state, Nigeria \\ Email: davidakaprof01@yahoo.com
}

Received: 28 March 2019; Accepted: 22 April 2019; Published: 08 May 2019

\begin{abstract}
Synchronous and asynchronous e-learning are two popular e-learning modes that are commonly used in distant learning education. The study investigates how synchronous and asynchronous e-learning affect the academic performance of students. A questionnaire was used to collect data for this study from some students of the National Open University of Nigeria. The findings showed that students' attitude to synchronous and asynchronous e-learning affect their academic performance. The results demonstrated that only $60 \%$ of the respondents understand what asynchronous and synchronous e-learning means. Also, only 55\% of the respondents believed that asynchronous and synchronous e-learning mode has a positive impact on their academic performance. Moreover, only 52\% of the respondents are of the opinion that the curriculum in use at National Open University needs to be updated to increase the impact of the e-learning mode on the learners.
\end{abstract}

Index Terms-Synchronous, Asynchronous, Distance learning, E-learning, real-time, self-paced

\section{INTRODUCTION}

Time is a very important factor in today's world where things are done very quickly. This has brought a paradigm shift in the pattern of learning [1]. The general public desires that learning should be consistent with their timetable irrespective of time and geographical location. The implication of this is that learning must be accessible all round the clock, with timely delivery to the workplace, residence, and place of vacation [1]. This has positioned information technology to serve as a viable innovative medium for a creative way of learning (elearning). Electronic learning or e-learning is any form of learning that uses a network (LAN, WAN or Internet) for delivery, communication, or simplification and the channel of teaching in computer. E-learning is an allencompassing word that incorporates the multimedia method of instructional delivery, learning via the internet, courseware or Computer Based Training (CBT), educational intranet, and Web-Based Training (WBT). Since e-learning uses a kind of approach that proceeds based on learners response, and proactive learning; it gives the learner a scintillating experience that might be more beneficial compared to the quality of education the learner is likely to experience in a jam-packed lecture hall. E-learning can either be synchronous, asynchronous, instructor-led or computer-based or a combination of both [1].

E-Learning was defined in [2] as any kind of learning that uses computer and communications technology. It is one of the fastest growing sectors of education and is becoming progressively popular in institutions of higher learning. [3] opined that the most primitive materialisation of e-learning happened in the 1970s with the introduction of Computer-Based Training (CBT) courses that uses mainframe computers. The drawback of these computers is that they have very limited capacity. They made it possible for users to choose the right answers to multiple choice questions and afterward comparing the result to the already created response. [4] was of the opinion that as technology is advancing and the horizon is getting broadened, several new electronic gadgets are now being used for learning the purpose, including audio and video tapes, teleconferencing, interactive TV and the Worldwide Web. The word elearning is now generally used to mean learning that is done or make possible at any rate via the Internet. Since access to the internet has greatly increased, e-learning has developed into a widespread and effectual approach to offer distance learning solutions.

[4] posited that e-learning occurs in one of two modes: asynchronous or synchronous. Asynchronous e-learning 
is principally self-induced and happens at learner's spare time and their chosen location. It can be done independently, by means of e-books or CD-ROM tutorials or with others, interacting over email, online bulletin boards, and discussion forums. Asynchronous elearning can be compared to synchronous (live) elearning which entails how one or more learners and the learning facilitator communicating in real-time [5]. It was concluded in [6] that the students' prior learning experiences, conceptions of learning, and study approaches underpin the quality of their learning outcomes. A higher percentage of learners in Nigeria learns through face to face, instructor-centered learning. With the use of ICT in Nigerian education, the question is on whether the use of this technology has a positive impact on learners experience and the learning outcomes.

The National Open University of Nigeria provides learning at a distance. This implies that it is not compulsory for students to be at chosen places and at certain times to listen to their lecturers, as is usually done in a traditional learning environment where students usually engage in a direct learning with teachers. Distance learning allows the students to do a sizable percentage of their learning away from the school premises and the lecturers. This implies that students are to a larger magnitude detached from the school and their lecturers in time and location and have to study on their own. The disadvantage of this learning approach is that it places great responsibility on students in terms of identifying the most appropriate way to study [7]. This method of education allows the physical posting of printed materials to students through the post office or courier companies. CD of recorded lectures in audio or video formats is provided as free media, depending on its availability and student's preference. Learning from a distance through Television and Radio broadcasts of the University's educational programmes are limited to the study centres which are situated nationwide. Some other challenges faced as deficiency of qualified academic staffs and in some situations only a few subscriptions. The experience of remote learners is greatly hampered by the drawbacks of this educational approach. This makes the students unenthusiastic to ask questions, not to be active in class discussion, and makes them develop undesirable attitudes towards the classes. This is the opposite of what is obtainable among learners that are physically co-situated with the lecturer and taking advantage of the face-to-face teaching [7].

The study investigates the asynchronous and synchronous delivery modes of e-learning in order to determine the merits of a live (synchronous) e-learning solution (e.g. LVCs) as compared to an asynchronous solution (e.g. email and the use of self-directed study modules, with interaction occurring over an online discussion forum). Also, to select an appropriate type of alternative e-learning solution by means of investigating the available applications (proprietary and open- source if all these options were available) of the chosen type. The study test, evaluate and critically analyse the chosen alternative e-learning solution in order to determine how successfully it addresses the current problems being experienced by some learners at NOUN, Maiduguri centre. This study will help the National Open University to develop and maintain effective synchronous and asynchronous learning communities that will enhance the academic performance of students. The study will also be useful as reference material for future research on elearning. The research motivation for this paper is born out of the need to answer some questions which can be summarised as follows:

1. What is the nature of Asynchronous and Synchronous e-learning modes in the National Open University of Nigeria, Maiduguri study centre?

2. What are the effects of asynchronous and synchronous e-learning modes skills on students' academic performance?

3. What is the structure of the curricula in the National Open University of Nigeria, Maiduguri Study Centre?

4. What is the structure of the asynchronous and synchronous e-learning mode that the National Open University of Nigeria, Maiduguri Study Centre teachers have adopted to suit the University curriculum?

The main focus of the research is on the impact of synchronous and Synchronous e-learning tools on students' performance in the National Open University of Nigeria (NOUN) [7]. This study concentrates on the use of e-learning for small, interactive academic in Maiduguri study centre of the National Open University of Nigeria. The use of LVCs for large groups (e.g. for large public webcast lectures), or in different environments (e.g. for use in industrial and corporate training), will not be explored. Although the research could be applicable to some Nigerian educational institutions of other kinds (e.g. much larger tertiary educational institutions or colleges) or at other levels (e.g. secondary education), these are considered beyond the scope of this particular study.

\section{RELATED WORKS}

The e-learning is not a new phenomenon in promoting education in some parts of the world. Presently, some institutions in Nigeria are using it to promote distance education (DE) and lifelong learning. The traditional context of learning is experiencing a radical change. There are many situations in which people want to learn exactly what they are interested in without time and location constraints. These kinds of needs require learning to be personalized, flexible, and available ondemand. The concept of traditional classroom education does not always fit comfortably into the new world of lifelong learning where the roles of instructors, students, and curriculum are changing. With the increasing use of networked computers and remarkable advances in telecommunication technologies, the Internet has been widely recognized as a valuable and inexpensive medium for network-enabled transfer of skills, information, and knowledge. 


\section{A. E-Learning System}

E-learning can be either synchronous or asynchronous. Synchronous e-learning requires the simultaneous participation of all learners and instructors at distributed locations. It refers to any learning event delivered to remote learners in real-time and includes immediate, twoway communication between participants. Therefore, synchronous e-learning is scheduled delivery of learning. Asynchronous e-learning does not require simultaneous participation of learners and instructors. It refers to any learning event that does not take place in real-time [8].

\section{Asynchronous E-learning System}

Asynchronous e-learning is a type of e-learning that makes learning available as soon as or whenever it is required, which gives the learners great flexibility in term of learning time, process and content. Many of the present e-learning systems offer asynchronous learning environments because they are easy to set up and are cheaper than synchronous e-learning methods [9]. Moreover, synchronous e-Learning is not flexible with respect to time. Extensive research has shown that in contrast to traditional classroom learning, e-learning has several advantages for learners $[10,11,12]$. Many studies have reported that e-learning is at least as effective as traditional classroom learning, measured by exam grades and learner's satisfaction $[10,13]$. While most literature emphasizes the benefits of e-learning, some researchers have also pointed out its drawbacks such as frustration, confusion, and a reduced interest in subject matters [14]. Early e-learning systems used text-based instructions only, which could make learners bored and disengaged during online learning [15]. With the latest advances of multimedia technology, a number of multimedia integrated learning systems have been developed [16]. Simply defined, the term "multimedia" refers to a computer-based system that provides asynchronous learning environments, since they are simpler to develop and are less expensive than synchronous e-learning systems.

Multimedia content, transmitted over ever-increasing network bandwidth, has a dramatic impact on both processes and products of learning. It provides a multisensory learning environment that can help maximize learners' ability to retain information [17], and entice learners to pay more attention to a task through vivid and rich presentations that are more intriguing and fascinating [18]. Many learners enroll in online courses because of their asynchronous nature, which needs to be taken into account [19]. For the discussion of complex issues, synchronous e-learning, by media such as video conferencing, instant messaging and chat, and arranging face to face meetings as a complement may be essential for students to know each other and for planning the tasks at hand. However, when discussing complex issues, in which time for reflection is needed, it is better to switch to asynchronous e-learning and use media such as e-mail, discussion boards, and blogs [20]. Asynchronous communication gives learners the freedom of choice in learning. This communication is not dependent on learners being present together at a specific time to conduct teaching and learning activities [21]. Asynchronous communication environment provides learners with the discussion that allows participant access to the conference or instruction at different times. Therefore, learners can work at their own convenience, when or where they want and at their own place, thereby providing learners more time to reflect on their own ideas and encourage them to do more critical thinking [21].

\section{Synchronous e-learning System}

Synchronous e-learning makes use of digital tools and content extending from telephone calls and videoconferencing to voice over internet protocol (VoIP) and video broadcast over the internet [19]. Some synchronous e-learning like the video-conferencing and Live Virtual Classrooms (LVCs) which is a blend of two or more synchronous technologies used to produce a solution that

Table 1. Synchronous e-learning technology and key issues

\begin{tabular}{|l|l|l|}
\hline Reference & Technology & \multicolumn{1}{c|}{ Key Issues } \\
\hline$[19,24]$ & Video conferencing & $\begin{array}{l}\text { - Allows real-time interaction among students just as in the traditional classroom } \\
\text { environment. } \\
\text { - Costly and successful implementation depends on the availability of bandwidth. }\end{array}$ \\
\hline$[22]$ & Web Conferencing & $\begin{array}{l}\text { - Allows sharing of documents, PowerPoint presentations, and demonstration of application } \\
\text { programs. } \\
\text { - Costly and successful implementation depends on the availability of bandwidth. }\end{array}$ \\
\hline$[23]$ & White boarding & $\begin{array}{l}\text { - Demonstration and co-development of ideas. } \\
\text { - Costly, its implementation depends on the availability of bandwidth. It is sometimes better } \\
\text { used with audio conferencing. }\end{array}$ \\
\hline$[23]$ & Audio conferencing & $\begin{array}{l}\text { - Allows students to engage in collaborative discussion. } \\
\text { - It is likely to be costly when it involves international participants. }\end{array}$ \\
\hline$[20]$ & Chat & $\begin{array}{l}\text { - Allows the sharing of textual and graphical information that is not too complex. } \\
\text { - Communication rate is slowed down since it is majorly text-based. }\end{array}$ \\
\hline & Instant messaging & $\begin{array}{l}\text { Allows messages to be delivered promptly. } \\
\text { The use of devices such as headset is required. It also allows one to one or one to many } \\
\text { interactions. }\end{array}$ \\
\hline
\end{tabular}


permits several channels of communication [22, 23]. For instance, video-conferencing brings together video and audio in an effort to reduce the experience of communicating with others face-to-face and is used both to accelerate meetings in business and industry, in addition to education purposes [24, 25]. LVCs integrate video and audio in a like fashion but are particularly intended for web-conferencing training, and education. They thus include a range of other tools intended to support interaction and distance learning, like collaborative whiteboards, analysing and resource grouping instruments, and contributor response tools. The progressions in technology have made it feasible for elearning communities to be launched as either synchronous or asynchronous [24]. Table 1 and 2 summarised the technologies and key issues in both asynchronous and synchronous e-learning systems.

Table 2. Asynchronous e-learning technology and key issues

\begin{tabular}{|c|c|c|}
\hline Reference & Technology & Key Issues \\
\hline$[20]$ & Email Messages & $\begin{array}{l}\text { - Allows the distribution of course materials to registered students. } \\
\text { - Getting instant reply can be difficult especially in a large class. }\end{array}$ \\
\hline [4] & E-books & $\begin{array}{l}\text { - Serves as an additional teaching and learning materials. } \\
\text { - It does not encourage an interactive mode of learning. } \\
\text { - It is not dynamic. }\end{array}$ \\
\hline [20] & Web blogs & $\begin{array}{l}\text { - Allows the exchange of ideas through educative posts and comments. } \\
\text { - Decisions and conclusions are not easily arrived at. }\end{array}$ \\
\hline$[20]$ & Discussion Forums & $\begin{array}{l}\text { - Encourage collaboration and exchange of ideas over some period of time. } \\
\text { - It usually takes time to arrive at decisions and conclusions. }\end{array}$ \\
\hline$[1]$ & Website links & $\begin{array}{l}\text { - It is used to redirect users to supplementary materials and references. } \\
\text { - Maintenance activities on the web server can make the resources the users are trying to } \\
\text { locate not to be available. }\end{array}$ \\
\hline [4] & Databases & $\begin{array}{l}\text { - Serve as the warehouse of teaching and learning materials, and also help in managing } \\
\text { them. } \\
\text { - Personnel with good managerial skills are needed to make it function optimally. }\end{array}$ \\
\hline$[4,19,22]$ & Streaming video & $\begin{array}{l}\text { - Lectures are delivered through playback of video for students to watch. } \\
\text { - It is not dynamic and interactive learning is not supported. }\end{array}$ \\
\hline$[4,19,22]$ & Streaming Audio & $\begin{array}{l}\text { - Lectures are done through playback of audio for students to listen to. } \\
\text { - It is not dynamic and interactive learning is not supported. }\end{array}$ \\
\hline [1] & Narrated slideshow & $\begin{array}{l}\text { - Lectures are delivered through playback for students to watch. } \\
\text { - It is not dynamic and interactive learning is not supported. }\end{array}$ \\
\hline [20] & Online bulletin boards & $\begin{array}{l}\text { - Allow teachers to take advantage of functional wall space. It can save time, keep } \\
\text { students informed and serve various purposes. } \\
\text { - They are costly and complex to implement. High maintenance cost is involved. Not } \\
\text { the best option in an environment where is there an inadequate power supply. } \\
\text { - They can also lead to clutter and confusion in class. }\end{array}$ \\
\hline
\end{tabular}

\section{METHODOLOGY}

This section describes the techniques that we used to determine the effects of Asynchronous and Synchronous e-learning on the performance of the students. The research design, population and sampling, the instrument of data collection and the method of data collection were described.

\section{A. Design of the study}

This study is centered on the impact of Asynchronous and Synchronous el earning mode on Nigerian students' learning outcome using the National Open University of Nigeria, Maiduguri study centre as a case study. The survey design was therefore employed to conduct the research. The design was purposely chosen so that the researcher will be able to collect information from groups of selected individuals known as a sample about issues, events, and relationships concerning a larger group known as the population and then generalizes the findings to the entire population.

\section{B. Population and Sample}

The population of the study composed of students and teachers, numbering about 2,000 in National Open University of Nigeria, Maiduguri study centre. Using the random sampling technique, a sample of 1,000 students and teachers, representing $50 \%$ of the target population, was used for the study. The sample was randomly drawn from among the students and teachers in the National Open University of Nigeria, Maiduguri study centre.

\section{Instrument for data collection}

The non-observational technique involving the use of questionnaire was employed as the research instrument to obtain relevant data for the study. Five hundred (500) questionnaires were administered to each of the students and some teachers sampled for the study. It is a selfdeveloped questionnaire with the experienced suggestion of the supervisor and the process of designing it took into consideration the major questions outlined for the study. The questionnaire is divided into two parts, namely 'Part 
$\mathrm{A}^{\prime}$ and Part B'. Part A concerns the personal data of respondents such as gender, age, university status, department and level of study. Part B of the questionnaire has to do with the research questions and it is divided into four sections. Each section has five items. Respondents were required to tick one of two options of yes' or no' at the end of each question.

\section{Method of data collection}

The questionnaires designed for the study were personally administered to respondents in the school after obtaining the necessary permission from the authority of the school. The questionnaires served as the primary source of data while textbooks, institutional e-books, and records downloaded from the National Open University website such as NOUN student handbook, getting to know your university and NOUN access programme collectively served as the secondary sources of data. Important information was also collected from some staffs of the university.

\section{E. Method of data analysis}

Since the study aims to essentially document the impact of Asynchronous and Synchronous e-learning mode on Nigerian students' learning outcome using National Open University of Nigeria, Maiduguri study centre, we employed the descriptive statistics using simple percentages. Descriptive statistics involves 'discovering the distribution of certain traits or attributes.' In this regard, the researcher is not concerned with why the observed distribution exists but merely what the distribution is. Kenneth Bailey, however, adds that "such explorations are often called descriptive studies because they attempt to describe phenomena in detail, in contrast to explanatory studies which generally attempt to explain a social phenomenon by specifying why and how it happened." The descriptive study tries to describe what is happening." In the process of describing this, it gathers information about the phenomenon, such as how it works and the individuals concerned. It then presents all this in a descriptive form to describe the true state of the phenomenon. The descriptive method of data analysis was chosen because it is very helpful in answering the question on the impact of Asynchronous and Synchronous e-learning mode on Nigerian students' learning outcome using National Open University of Nigeria, Maiduguri study centre. A proper understanding of all these will help the researcher to make important recommendations that may improve the implementation of Asynchronous and Synchronous e-learning mode in National Open University of Nigeria, Maiduguri study centre.

\section{Result, DAta PRESENTAtion, AND ANALYsis}

This section deals with data presentation and analysis. The results are presented in the following tables. What is the nature of Asynchronous and Synchronous e-learning modes in the National Open University of Nigeria, Maiduguri study centre?

\section{A. Percentage Distribution of Respondents on Nature of Asynchronous and Synchronous E-learning}

\section{Data Presentation Research Question One}

Table 3 and figure 1 showed the Percentage distribution of respondents based on their understanding of the nature of Asynchronous and Synchronous elearning modes in the National Open University of Nigeria Maiduguri study centre.

Table 3. Percentage distribution of respondents' responses on the nature of Asynchronous and Synchronous e-learning modes in National Open University of Nigeria Maiduguri study centre.

\begin{tabular}{|l|l|l|}
\hline \multicolumn{2}{|l|}{$\begin{array}{l}\text { Nature of asynchronous and synchronous } \\
\text { e-learning modes }\end{array}$} & \multicolumn{2}{|l|}{ of } \\
Respondents \\
Yes
\end{tabular}

Table 4 and figure 2 is based on the question asked in the previous section that what are the effects of asynchronous and synchronous e-learning modes skills on students' academic performance.

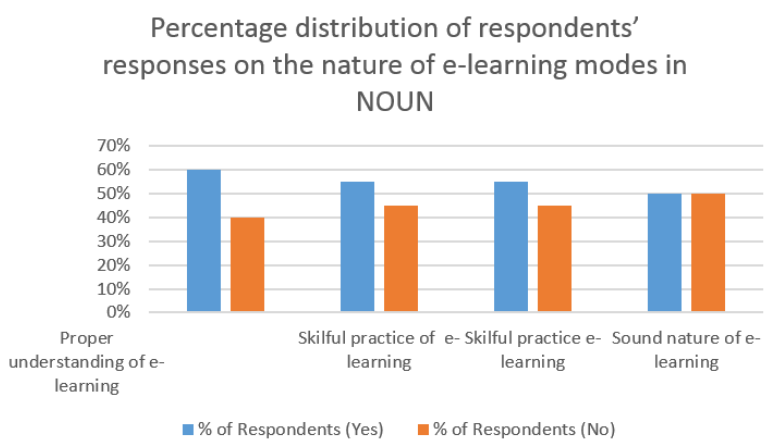

Fig.1. Percentage distribution of respondents' response on the nature of e-learning modes in NOUN

Table 4. Percentage distribution of respondents' responses on the effectiveness of Asynchronous and Synchronous e-Learning modes in National Open University of Nigeria Maiduguri study centre

\begin{tabular}{|l|l|l|}
\hline $\begin{array}{l}\text { Areas of the effectiveness of } \\
\text { asynchronous and synchronous e- } \\
\text { learning modes }\end{array}$ & $\begin{array}{l}\text { \% } \\
\text { respondent } \\
\text { Yes }\end{array}$ & No \\
\hline Effectiveness on student's study habit & $55 \%$ & $48 \%$ \\
\hline $\begin{array}{l}\text { Effectiveness on student's knowledge and } \\
\text { skills }\end{array}$ & $60 \%$ & $40 \%$ \\
\hline $\begin{array}{l}\text { Effectiveness on student's classroom } \\
\text { participation }\end{array}$ & $50 \%$ & $50 \%$ \\
\hline Effectiveness on student's motivation & $60 \%$ & $40 \%$ \\
\hline Effectiveness on student's mental alertness & $55 \%$ & $45 \%$ \\
\hline
\end{tabular}


Areas of effectiveness of asynchronous and synchronous e-learning modes

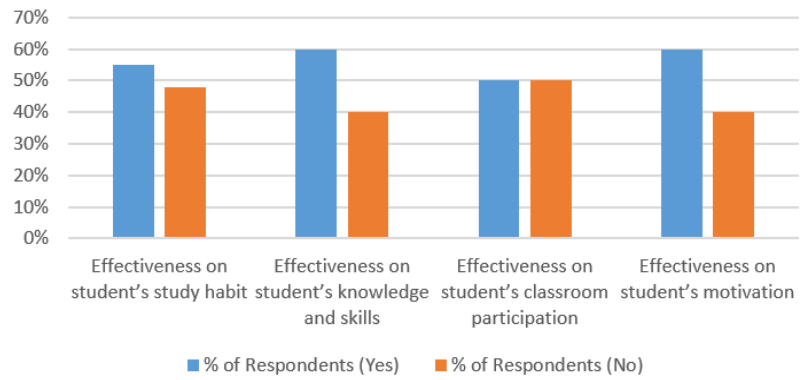

Fig.2. Percentage distribution of respondents' responses on the effectiveness of e-learning in NOUN

Table 5 and figure 3 show the percentage distribution of respondents' response on the structure of the curriculum used in NOUN research question three. What is the structure of the curricula in the National Open University of Nigeria, Maiduguri Study Centre?

Table 5. Percentage distribution of respondents' response on the structure of the curriculum

\begin{tabular}{|l|l|l|}
\hline $\begin{array}{l}\text { Effect of the structure of the curriculum } \\
\text { on teachers and students }\end{array}$ & $\begin{array}{l}\text { \% of } \\
\text { Respondents } \\
\text { Yes }\end{array}$ & No \\
\hline The structure of the curriculum is sound & $48 \%$ & $52 \%$ \\
\hline $\begin{array}{l}\text { The teacher has an influence in deciding the } \\
\text { structure of the curriculum }\end{array}$ & $45 \%$ & $55 \%$ \\
\hline $\begin{array}{l}\text { The structure of the curriculum needs to be } \\
\text { reformed }\end{array}$ & $60 \%$ & $47 \%$ \\
\hline $\begin{array}{l}\text { The structure of the curriculum may be } \\
\text { sustained with slight modification }\end{array}$ & $45 \%$ & $55 \%$ \\
\hline $\begin{array}{l}\text { The present school curriculum affects } \\
\text { students' academic performance negatively }\end{array}$ & $65 \%$ & $35 \%$ \\
\hline
\end{tabular}

Effect of the structure of curriculum on teachers and students

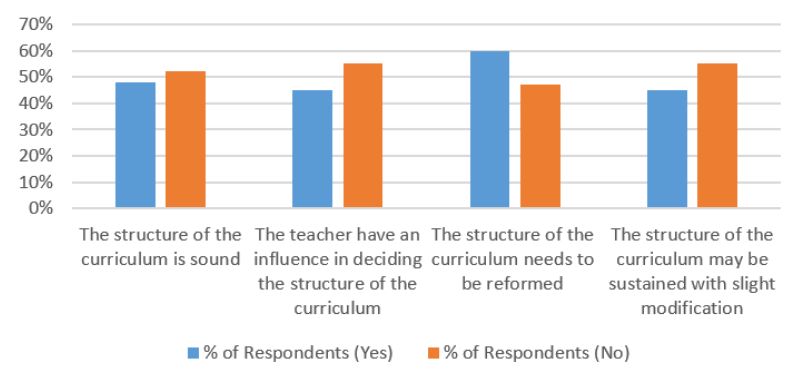

Fig.3. Percentage distribution of respondents' response on the structure of the curriculum

Percentage Distribution of Respondents' Responses on the Structure of Asynchronous and Synchronous ELearning Mode in NOUN

Our discussion here is based on research question four that says that what is the structure of the asynchronous and synchronous c-learning mode that the National Open University of Nigeria, Maiduguri Study Centre teachers have adopted to suit the University curriculum? Table 6 and figure 4 depict the responses of the students to the structure of e-learning modes in NOUN.
Table 6. Percentage distribution of respondents' responses on the structure of asynchronous and synchronous e-learning mode that the national open University of Nigeria, Maiduguri study centre teachers have adopted to suit the University curriculum.

\begin{tabular}{|l|l|l|}
\hline \multirow{2}{*}{$\begin{array}{l}\text { Structure of asynchronous and synchronous } \\
\text { e-learning mode that the national open } \\
\text { university of Nigeria, Maiduguri study centre } \\
\text { teachers have adopted to suit the university } \\
\text { curriculum }\end{array}$} & Respondents \\
\cline { 2 - 4 } & Yes & No \\
\hline $\begin{array}{l}\text { Teachers find it difficult to marry the structure } \\
\text { of their asynchronous and synchronous e- } \\
\text { learning mode plan with the university } \\
\text { curriculum }\end{array}$ & $50 \%$ & $50 \%$ \\
\hline $\begin{array}{l}\text { The present university curricula render teachers' } \\
\text { asynchronous and synchronous e-learning mode } \\
\text { plan ineffective }\end{array}$ & $55 \%$ & $45 \%$ \\
\hline $\begin{array}{l}\text { The present university curricula impact } \\
\text { negatively on teachers' asynchronous and } \\
\text { synchronous c-learning mode plan }\end{array}$ & $58 \%$ & $42 \%$ \\
\hline $\begin{array}{l}\text { Government need to do more to encourage } \\
\text { teachers to developed asynchronous and } \\
\text { synchronous e-learning mode plan }\end{array}$ & $65 \%$ & $35 \%$ \\
\hline $\begin{array}{l}\text { My present asynchronous and synchronous e- } \\
\text { learning made techniques are well suited to the } \\
\text { current university curricula }\end{array}$ & $52 \%$ & $48 \%$ \\
\hline
\end{tabular}

Structure of asynchronous and synchronous elearning mode

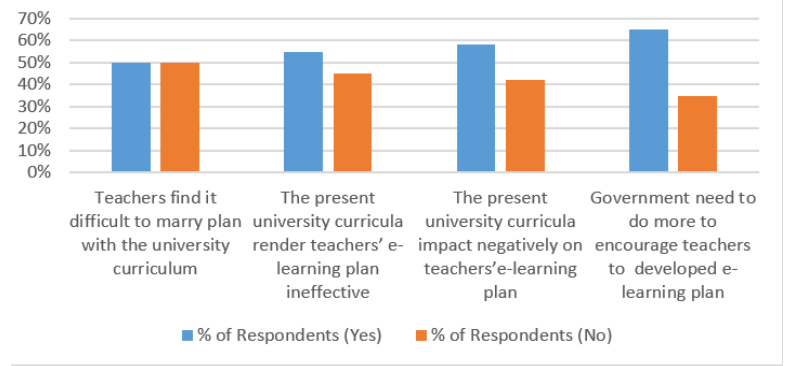

Fig.4. Percentage distribution of respondents' responses on the structure of asynchronous and synchronous e-learning mode in NOUN

\section{B. Data Analysis}

This section provides information on the analysis of the study based on the table obtained from our study.

Data Analysis of Percentage Distribution of Respondents on Nature of Asynchronous and Synchronous E-learning

Results presented in table 1 show that $60 \%$ of students surveyed agreed that they have a proper understanding of asynchronous and synchronous e-learning modes. Approximately $55 \%$ of the students learn through asynchronous and synchronous e-learning modes with great skills. Students who practice asynchronous and synchronous e-learning modes of a sound nature are approximately $50 \%$. Approximately $45 \%$ of students surveyed exhibit motivational asynchronous and synchronous e-learning modes skills. These are skills that have to do with students who have low motivation and who have a history of misbehaviour in school. 


\section{Data Analysis of Percentage Distribution of Respondents' Responses on The Effectiveness of Asynchronous and Synchronous E-learning}

Results presented in table 2 show that approximately $55 \%$ of students surveyed agreed that effective use of asynchronous and synchronous e-learning mode skills positively influenced the study habits of students. The implication of this is that there is an improvement in students' academic performance. Approximately $60 \%$ of students surveyed agreed that effective use of asynchronous and synchronous e-learning mode skills positively affect students' knowledge and skills. This has to do with students' ability to synthesize and apply conceptual principles.

One important asynchronous and synchronous elearning mode technique is getting students to participate actively in class activities such as assignments and mini projects through email, live chat, etc. Approximately 50\% of respondents agreed that their asynchronous and synchronous e-learning mode skills are very helpful in making students active in class work. Approximately $60 \%$ of respondents agreed that their asynchronous and synchronous e-learning mode skills are very helpful in getting students with a low-motivation problem to be motivated. A good percentage of students surveyed (55\%) agreed that their asynchronous and synchronous elearning mode skills are very effective at getting students to improve their mental alertness.

Data Analysis of Percentage Distribution of Respondents' Response on the Structure of Curriculum Used in NOUN

Results presented in table 3 show that $52 \%$ of teachers surveyed disagreed that the structure of the curriculum at the National Open University of Nigeria is sound. On the other hand, only $45 \%$ of teachers surveyed agreed that teachers have an influence on decisions taken concerning school curriculums. Approximately $60 \%$ of the teachers surveyed agreed that the structure needs to be reformed. On sustaining the curriculum structure with slight modification, approximately $55 \%$ of respondents agreed that the present structure needs to be modified. Approximately $65 \%$ of respondents agreed that the present structure affects students' academic performance negatively.

Data Analysis of Percentage Distribution of Respondents' Responses on the Structure of Asynchronous and Synchronous e-learning Mode in NOUN

Results presented in table 4 show that $50 \%$ of teachers surveyed agreed that they find it difficult to marry the structure of their classroom management plan with the present school curricula. Approximately 55\% of teachers surveyed agreed that the present University curriculum renders their asynchronous and synchronous e-learning mode plan ineffective. On the impact of the school curriculum on teachers asynchronous and synchronous clearning mode plan, $58 \%$ of those surveyed agreed that it is negative. Out of the teachers surveyed, $65 \%$ agreed that the government is not doing enough to encourage them to develop effective asynchronous and synchronous el earning mode plan. Approximately $52 \%$ of the number surveyed agreed that their asynchronous and synchronous e-learning mode techniques are well suited to the current University curricula.

\section{Data Discussion}

This section gives a brief discussion of the analysis of the study done in the last section.

Data Discussion of Percentage Distribution of Respondents on Nature of Asynchronous and Synchronous E-learning

From our study, it is evident that about $60 \%$ of students agreed that they have a proper understanding of asynchronous and synchronous e-learning modes. Approximately $55 \%$ of the students learn through asynchronous and synchronous e-learning modes with great skills. Students who practice asynchronous and synchronous e-learning modes of a sound nature are approximately $50 \%$. Approximately $45 \%$ of students surveyed exhibit motivational asynchronous and synchronous e-learning modes skills. This agrees with the findings of [26] that concluded that the awareness of clearning among the Universities is very high but investment and commitment to developing an e-learning application is very poor and below expectation according to the study. [27] also agree that e-learning is simple and adoptable.

Data Discussion of Percentage Distribution of Respondents' Responses on the Effectiveness of Asynchronous and Synchronous E-Learning

Approximately 55\% of students surveyed agreed that effective use of asynchronous and synchronous e-learning mode skills positively influenced the study habits of students. The implication of this is that there is an improvement in students' academic performance. Approximately $60 \%$ of students surveyed agreed that effective use of asynchronous and synchronous e-learning mode skills positively affect students' knowledge and skills. About $50 \%$ of respondents agreed that their asynchronous and synchronous c-learning mode skills are very helpful in making students active in class work. Approximately $60 \%$ of respondents agreed that their asynchronous and synchronous e-learning mode skills are very helpful in getting students with a low-motivation problem to be motivated. A good percentage of students surveyed $(55 \%)$ agreed that their asynchronous and synchronous e-learning mode skills are very effective at getting students to improve their mental alertness. These agreed with the findings of [28] who in their conclusion found that asynchronous and synchronous e-learning mode skills are very helpful in making students active in class work. 
Data Discussion of Percentage Distribution of Respondents' Response on The Structure of Curriculum Used in NOUN

About $52 \%$ of teachers surveyed disagreed that the structure of the curriculum at the National Open University of Nigeria is sound. On the other hand, only $45 \%$ of teachers surveyed agreed that teachers have an influence on decisions taken concerning school curriculums. About $60 \%$ of the teachers surveyed agreed that the structure needs to be reformed. On sustaining the curriculum structure with slight modification, approximately $55 \%$ of respondents agreed that the present structure needs to be modified. About $65 \%$ of respondents agreed that the present structure affects students' academic performance negatively. This agrees with the findings of [27] who in their research posited that most of the students admitted by NOUN have no information technology/computer education knowledge because it was not entrenched in the curriculum at their elementary and secondary education level.

Data Discussion of Percentage Distribution of Respondents' Responses on the Structure of Asynchronous and Synchronous E-Learning Mode in NOUN

About $50 \%$ of teachers surveyed agreed that they find it difficult to marry the structure of their asynchronous and synchronous e-learning mode plan with the present school curricula. About 55\% of teachers surveyed agreed that the present University curriculum renders their asynchronous and synchronous e-learning mode plan ineffective. On the impact of the school curriculum on teachers' asynchronous and synchronous c-learning mode plan, $58 \%$ of those surveyed agreed that it is negative. Out of the teachers surveyed, $65 \%$ agreed that the government is not doing enough to encourage them to develop effective asynchronous and synchronous elearning mode plan. This agree with the findings of [26] who opined that most of the staff and students in the universities only use Internet-related e-learning site just for the sake of finding related information for their researches, since their libraries cannot afford to provide them with adequate and current materials but not for the sake of real online learning. Approximately 52\% of the number surveyed agreed that their asynchronous and synchronous e-learning mode techniques are well suited to the current University curricula.

\section{FINDINGS OF THE STUDY}

i. The results revealed that $60 \%$ of respondents have an understanding of asynchronous and synchronous e-learning mode;

ii. The results also revealed that $55 \%$ of respondents agreed that the effects of asynchronous and synchronous e-learning mode on the academic performance of students are positive; iii. The results revealed that $52 \%$ of respondents do not agree that the structure of the curriculums in the National Open University of Nigeria is sound.

iv. Lastly, the results revealed that the present University curricula render teachers' asynchronous and synchronous e-learning mode plan ineffective.

\section{DISCUSSION}

As a descriptive study, statistical data were analyzed using simple percentages. The study provided valuable insight into the relationships between various aspects of teachers' asynchronous and synchronous e-learning mode practices and students' academic performance. The study confirmed that regardless of the level of preparation students bring into the class, decisions that the teachers make about the asynchronous and synchronous e-learning mode practices can either greatly improve students' academic performance or serve as an obstacle to it. The study related a few professional development experiences of teachers to their asynchronous and synchronous elearning mode practices; and relates this to students' academic performance. The study found positive relationships between performance-oriented asynchronous and synchronous e-learning mode practices and students' academic performance as well as between performance-oriented oriented professional development and performance-oriented oriented asynchronous and synchronous e-learning mode practices. The main findings of the study were based on four questions which were answered. The answers were sorted out and analyzed.

The questionnaire designed for the study was divided into two parts namely A and B. Part A aims to find out the personal data of respondents such as gender, age. school and nationality. Part B, on the other hand, was divided into four sections. Section 1 was aimed at finding answers to the first research question on the nature of asynchronous and synchronous e-learning mode skills practiced in the National Open University of Nigeria, Maiduguri study centre. Section 2 was aimed at finding out answers to the second research question which is on the effects of asynchronous and synchronous e-learning mode skills on students' academic performance. Section 3 was aimed at finding out answers to the third research question on the structure of National Open University of Nigeria curriculum. Finally, the fourth section aimed to find out answers to the research question on the structure of asynchronous and synchronous e-learning mode plan National Open University of Nigeria teachers adopted to suit the University curriculum. Each of the sections has five questions with the two options of a 'yes' or no' from which the respondents are expected to select one. 


\section{CONCLUSION AND FURTHER RESEARCH}

This research work is a study on the impact of asynchronous and synchronous el earning mode and its learning outcome on students' performance in the National Open University of Nigeria. Questionnaires were distributed to respondents which include both the students and teachers in the University. The results of the analysis revealed that $60 \%$ of respondents have an understanding of asynchronous and synchronous elearning mode. The results also revealed that $55 \%$ of respondents agreed that the effects of asynchronous and synchronous e-learning mode on the academic performance of students are positive. The results revealed that $52 \%$ of respondents do not agree that the structure of the curriculums in the National Open University of Nigeria is sound. Lastly, the results revealed that the present University curricula render teachers' asynchronous and synchronous e-learning mode plan unproductive.

This research has been able to establish that there is a relationship between a teacher's asynchronous and synchronous e-learning mode practices and students' academic performance. The study suggests that the decisions teachers make about asynchronous and synchronous e-learning mode practices can either strongly facilitate students' learning or serve as an obstruction to it. The study also found a positive relationship between performance-oriented asynchronous and synchronous e-learning mode practices and students achievement as well as between performance oriented professional development and performance oriented asynchronous and synchronous e-learning mode practices. Teachers' inputs will be least likely to influence students' academic performance because they do so less directly through encouraging asynchronous and synchronous elearning mode practices for higher performance among students. Professional development falls somewhere between asynchronous and synchronous e-learning mode practices and teacher inputs.

Teachers use asynchronous and synchronous e-learning mode to shape the learning environment into a safe, productive, lively and effective place. For this purpose, it is recommended that teachers should be required to undergo staff development courses or programmes on the use of Information and Communication Technology (ICT) at least once a year. This will expose them to new ideas in the use of asynchronous and synchronous e-learning mode practices, including modem assessment procedures which have implications for student motivation, learning process, and performances. The predominant usage of the conventional method of teaching by the teachers contributes to the poor performance of students. For this reason, professional bodies such as the National University Commission (NUC) should organize seminars, workshops and in-house training for the National Open University of Nigeria teachers on modern teaching methods. It is recommended that both the federal and state government should increase the salaries and allowances to meet with international standard. This will serve as a means of encouraging them to work harder.

Future researchers should broaden the sample to include both teacher and students from other study centres of the National Open University of Nigeria to ascertain the impact of Asynchronous and Synchronous e-learning mode on the students' learning outcome. [25] further observed that with e-learning rapidly gaining ground both in educative and corporate environments, there has been a profession of varied media of institution. It is rather interesting that all those media are based either on synchronous communication techniques or asynchronous communication techniques. Synchronous and asynchronous e-learning is about how and when learning takes place. The e-learning community can be viewed as an area where one can access practical/theoretical as well as hands-on resources for skill acquisition. One can connect with peers as well as lecturers and tutors for advice and knowledge that will help during the learning process. The advancement in technology has made it possible for e-learning communities to be set up as either synchronous or asynchronous. However, the main challenge facing higher education when implementing e-learning is whether to set up a synchronous or asynchronous community. This is mainly due to the lack of research evidence on how the learners benefit from these communities.

\section{REFERENCES}

[1] J. R. Still. E-Learning - Technology Blended With Education, 2017. Available at https://computer-sciencedegree.org/e-learning-technology-blended-with-education/

[2] Vicent-Lancring, S. OECD Policy Brief: E-learning in Tertiary Education [Online], 2005. Retrieved from http://www.oecd.org/dataoecd/27/35/35991871.pdf.

[3] Clark, R.C.F. and Mayer, R.E. E-learning and the science of instruction. San Francisco, USA, Pfeiffer, 2003.

[4] Hofman, J. The Synchronous Trainer's Survival Guide. California, USA. Pfeiffer, 2004.

[5] Van Dan, N. The e-learning field book. New York, USA. McGrawHill, 2004.

[6] Gravoso, R., Pasa, A. and Mori, T. "Influence of students' prior learning experiences, learning conceptions, and approaches on their learning outcomes, Quality conversations." Proceedings of the 2002 Annual International Conference of the Higher Education Research and Development society of Australia (HERDSA), HERDSA, Edith Cowan, 2002. Retrieved from

www.cowan.edu.au/conferences/herdsa/main/papers/ref/p df/gravoso.pdf

[7] NOUN. Getting to know your University - An orientation and information guide of National Open University of Nigeria, 2006. Retrieved on December 10, 2018, from www.noun.edu.ng

[8] Kaneko, A., Sugino, N., Suzuki, T. and Ishijima, S. "A step towards the smart campus: A venture project based on distance learning by a hybrid video conferencing system." In IEEE Conference on Systems, Man and Cybernetics, Nashville, TN, USA, 2000, pp. 38-43.

[9] Hammond, N., McKendree, J., Reader, W., Trapp, A. and Scott, P. The PsyCLE project: Educational multimedia for 
conceptual understanding. In ACM Multimedia 95, San Fransisco, California, USA, 1995, pp. 447-456.

[10] Burgstahler, S. "Teaching on the Net: What's the difference?" T.H.E. Journal, vol. 24, issue 9, pp. 61-64, 1997.

[11] Hiltz, E.S.R and Wellman, B. "Asynchronous learning networks as a virtual classroom." Communications of the ACM, vol. 40, issue 9, pp. 44-49, 1997.

[12] Piccoli, G., Ahmad, R. and Ives, B. "Web-Based Virtual learning Environments: A Research Framework and a Preliminary Assessment of Effectiveness in basic IT Skills Training." MIS Quarterly, vol. 25, issue 4, pp. 401-426, 2001.

[13] Amir, F., Iqbal, S.M. and Yasin, M. "Effectiveness of Cyber-learning" in 29th ASEE/IEEE Frontiers in Education Conference, San Juan, Puerto Rico, 13a12-17 13a12-12, 1999.

[14] Hara, N. and Kling, R. "Students' distress with a Webbased distance education course: an ethnographic study of participants' experience." Information, Communication, and Society, vol. 3, pp. 44-49, 2000.

[15] Wade, V.P. and Power, C. "Evaluating the Design and Delivery of WWW Based Educational Environments and Courseware", ACM ITICME, 1998, pp. 243-248, 1998.

[16] Merchant, S., Kreie, J. and Croan, T.P. "Training end users: Assessing the effectiveness of multimedia CBT." Journal of Computer Information Systems, Spring 2001, pp. 20-25, 2001.

[17] Syed, M. R. "Diminishing the distance in distance education." IEEE Multimedia, vol. 8, issue 3, pp. 18-21, 2001.

[18] Agius, H.W. and Angelides, M.C. "Developing knowledge-based intelligent multimedia tutoring systems using semantic content-based modelling." Artificial Intelligence Review, vol. 13, pp. 55-83, 1999.

[19] Simonson, M., Smaldino, S., Albright, M., and Zvacek, S. Teaching and learning at a distance: Foundations of distance education. (5th ed.). Boston: Pearson, 2012.

[20] Martinez-Caro, E. "Factors affecting effectiveness in elearning: An analysis in production management courses." Computer Applications in Engineering Education, 19(3), pp. 572-581, 2011. Retrieved from http://illiad.ncu.edu/illiad/illiad.dll?SessionID= P134743944M\&Action $=10 \&$ Form $=75 \&$ Value $=56443$

[21] Diaz, L. A., \& Entonado, F. B. "Are the functions of teachers in e-learning and face-to-face learning environments really different?" Educational Technology \& Society, 12(4), pp. 331-343, 2009. Retrieved from http://proxy1.ncu.edu/login?url=http://search.ebscohost.co $\mathrm{m} /$ login. asp $\mathrm{x}$ direct $=$ true $\& \mathrm{db}=\mathrm{ehh} \& \mathrm{AN}=44785119 \&$ site $=$ eds-live

[22] Halse, M., and Mallinson, B. "Investigating popular Internet applications as supporting e-learning technologies for teaching and learning with Generation Y." International Journal of Education and Development using ICT [Online], 5(5), 2009. Available: http://ijedict.dec.uwi.edu/viewarticle.php?id=861.

[23] Bonk, C., and Zhang, K. "Introducing the R2D2 model: Online learning for the diverse learners of this world." Distance Education, 27(2), pp. 249-264, 2006. doi:10.1080/01587910600789670

[24] Michelle Louise Halse. The Development and Evaluation of a Custom-built Synchronous Online Learning Environment for Tertiary Education in South Africa. Master's Thesis, Rhodes University, South Africa, 2007.
[25] Reynolds, P., Mason, R., Carol, F., Eaton, K. and Odell, E. "From Videoconferencing to Webcasting." In Proceedings of 2000. Chesapeake, USA: AACE, 2000.

[26] Manir, A.K. Problems, challenges and Benefits of implementing E-learning in Nigeria. International Journal of Emerging Technology in learning, vol. 4, issue 1, pp. 66-72, 2009. doi:10.3991/ijet.v4i1.653.

[27] T. O. Ajadi, O. I. Salawu and F. A. Adeoye. "E-learning and Distance Education in Nigeria," TOJET, vol. 7, no. 4, pp. 61-70, 2008.

[28] L. O. Odia and S. I. Omofonmwan. "Educational System in Nigeria Problems and Prospects", J. Soc. Sci., vol. 14, no. 1, pp. 81-86, 2007.

\section{Authors' Profiles}

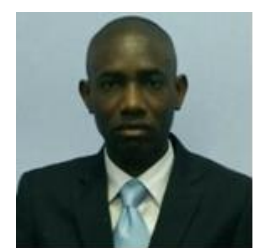

Dr. Emmanuel G. DADA received his $\mathrm{PhD}$ in Computer Science from Universiti Malaya, Malaysia (UM), MSc in Computer Science from University of Ibadan, Ibadan (UI), Nigeria and a Bachelor of Technology in Computer Science from the University of Ilorin, Ilorin, Nigeria. His current research interests are in Softcomputing Techniques, Machine Learning Algorithms, Image Segmentation, Swarm Robotics, Cyber Security and Big Data. He has published several academic papers in reputable International and local journals, conference proceedings and book chapters. He has been appointed as a reviewer of several ISI and Scopus indexed International journals such as ACM Survey, IEEE Access, Lecture Notes in Computational Vision and Biomechanics. He is presently a Senior Lecturer at the Department of Computer Engineering, University of Maiduguri, Nigeria.

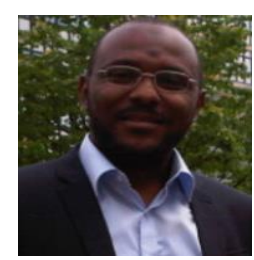

Dr. Abdulkadri H. Alkali received his Ph.D. and MEng in Electrical and Electronic Engineering from Sheffield Hallam University, UK. His current research interests are in Image Processing \& Computer Vision, Thermal Imaging, Medical Electronics, and Computer Network. He is a member of IEEE, COREN Rgd, MNSE, MNCS, MIET, AEEC. He is presently a Senior Lecturer at the Department of Computer Engineering, University of Maiduguri, Nigeria.

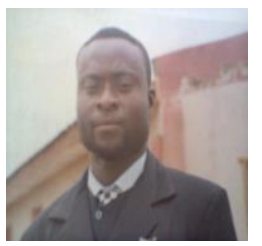

Dr. David O. Oyewola holds a Ph.D. in Applied mathematics from the Federal University of Technology Minna. He also has MSc in Financial Mathematics from Federal University of Technology Minna, Nigeria. His research interests include Financial Mathematics, Artificial Intelligence, and Machine Learning Algorithms. 
How to cite this paper: Emmanuel G. Dada, Abdulkadir H. Alkali, David O. Oyewola, "An Investigation into the Effectiveness of Asynchronous and Synchronous E-learning Mode on Students' Academic Performance in National Open University (NOUN), Maiduguri Centre", International Journal of Modern Education and Computer Science(IJMECS), Vol.11, No.5, pp. 54-64, 2019.DOI: 10.5815/ijmecs.2019.05.06 